\title{
Floating Hotel Docking Situation Assessment between Aswan and Luxor, Egypt
}

\author{
W.A. Fahmy ${ }^{1}$ and Nasr Hekal ${ }^{2}$
}

${ }^{1}$ Lecturer, Civil Engineering Department, Shoubra Faculty of Engineering, Benha University, e-mail: wael.ahmed@feng.bu.edu.eg, wailfahmy@yahoo.com

${ }^{2}$ Associate Professor, Nile Research Institute, National Water Research Center, Delta Barrages, Egypt, e-mail: nasr_hekal@nwrc.gov.eg, nasrhekal@gmail.com

\begin{abstract}
Because of the currently aggravating floating hotel (flotel) docking situation along the River Nile between Aswan and Luxor, this study aims to assess the present and future situation using historical data analysis. The flotel number in 2006 was obtained and that of 2035 was predicted by linear extrapolation. Dimensions of 2006 flotels were analyzed to determine the representative flotel. The analysis revealed a flotel of 75-m length, 15-m width and 1.8-m draft. Real data of tourist trips between Aswan and Luxor including other tourist cities such as Kom-ombo, Edfu, and Esna were utilized to determine the actual number of cruises that dock at each tourist site in years 2006 and 2035 considering that a flotel needs a 90-m length to dock at the river bank in one single row. The capacities required at each site were also estimated for 2006 and 2035. The study revealed that docking in one single row was inadequate and critical in 2006 and would be much worse in 2035. It was also warned of inshore docking in adjacent multiple rows since it causes delays, long waits and difficulty in maneuverability during taking off. Accordingly, a jetty arrangement of multiple spaced rows was proposed to improve the docking capacities at the tourist sites.
\end{abstract}

Keywords: River Nile, Inland Navigation, Floating Hotels, Docking Capacity

\section{Introduction}

Floating hotels are large boats/ships structurally designed of multiple storeys to carry and accommodate people in their journeys along rivers and seas. The name can be abbreviated as "flotels" as stated by (Wikipedia, 2020) [1]. Flotels have multiple uses. People use them for tourist cruising along rivers and visiting tourist attractions, especially those near the riversides. Moreover, flotels are used to house the working people, especially in the offshore oil industry and ocean bathymetry surveys who are obliged to stay for long times away from land. On the other hand, when land is scarce or fully developed, a flotel can be used as an alternative option for permanent residency as stated by (Admares, 2020) [2].

In river reaches abounding in tourist cruising, two main things should be guaranteed for flotels; safe navigable channels and sufficient berths to dock at. Navigable channels should be planned and designed such that they provide sufficient navigational water widths and depths for such flotels. Also, a sufficient number of river bank berths and ports should be fully constructed to absorb the whole number of the flotels journeying through the river reach of concern.

In general, worldwide inland traffic abundance through rivers basically depends on the availability of improved navigable channels and a sufficient number of docking berths and ports. Accordingly, improving inland navigation in Egypt through the River Nile main waterway and navigable branches such as Damietta could be considered a high priority. Continuous efforts have been exerted to satisfy the local needs for safe inland navigation through the main river waterway over a distance of $953 \mathrm{~km}$ between Aswan and Cairo and about 210 $\mathrm{Km}$ along the total length of Damietta branch.

To achieve safe visual navigation along the River Nile within Egypt, two major projects from 1998 to 2009 were undertaken by the River Transport Authority "RTA", an affiliation to the Ministry of Transport, in cooperation with the Nile Research Institute "NRI", a river engineering consultant affiliated to the National Water Research Center "NWRC", an affiliation to the Ministry of Water Resources and Irrigation. The major objective of such projects was to enhance navigation through the River Nile main waterway and Damietta branch and their social and economic impacts on the national development program that leads to improving the inland navigation share from $1 \%$ to about $6 \%$ of the total transported goods and raw materials of the country (Lashine, 2015) [3].

The two projects comprised some works. For instance, an intensive bathymetric survey was conducted along the different reaches of the River 
Nile and Damietta branch to identify the river morphology including water depths. Contour maps for the riverbed were produced accordingly. Also, the minimum water stages over the previous 15 years (1990-2005) at the different gauging stations deployed along the river banks were analyzed. Then, a two-way navigable channel route was planned and designed to allow the passage of two loaded design ships meeting at normal speed. Also, the designed navigable channel took into account the overtaking of the design ship by another one. Four design approaches for the navigable channel were applied taking into account the recommendations of (McAleer et al, (1963) [4], Wicker (1971) [5], Kray (1973) [6], Herbich (1986) [7], Willingford (1996) [8], PIANC (1997) [9], CCG (2001) [10], El Sersawy et al (2005) [11], PIANC (2014) [12]). Moreover, the modern design techniques of the "Permanent International Association of Navigation Congresses" (PIANC) and the "International Association of Ports and Harbors" (IAPH) were used to determine the firstclass navigable channel dimensions. Navigable channel widths of $100 \mathrm{~m}$ and $40 \mathrm{~m}$ were recommended for the River Nile main waterway and Damietta branch respectively. Finally, dredging works were carried out to provide and guarantee a $2.30 \mathrm{~m}$ clear water depth during the lowest water stage.

In this way, safe navigable channels could be constructed to absorb the navigation traffic in Egypt which comprises both of the cargo transportation vessels and floating hotels.

\section{Current Status of River Transport Vessels in Egypt}

River transport is usually prioritized over other modes of transport for its cheap, clean and appropriate environmental conditions. In Egypt, inland transport is capable of transporting loads exceeding $30 \mathrm{~m}$ in length and 400 tons in weight. About $75 \%$ of the available different types and sizes of vessels are locally designed and manufactured with sufficient experience and high quality, as stated by (RTA, 2006) [13]. The pusher barge, pushed dump barge and tourist flotels are considered the most common navigation units in Egypt. The total navigation vessels were classified by the end of year 2010 as shown in Table 1.

Table 1: Number of river transport vessels in Egypt (Source: RTA, 2006)

\begin{tabular}{c|l|c}
\hline No. & \multicolumn{1}{c|}{ Division } & Total number \\
\hline 1 & River Transport Company & 240 \\
2 & Water Transport Company & 216 \\
3 & Sugar Refining Factory & 191 \\
4 & Private Sector & 4418 \\
5 & Public Sector & 256 \\
6 & Governmental Units $\quad$ Total Number & 325 \\
\hline \multicolumn{1}{|c}{} \\
\hline
\end{tabular}

As for the navigation infrastructure development throughout the River Nile, substantial efforts have been exerted since the construction of Delta Barrages in 1867. All the barrages established across the river have been equipped with navigation lock chambers that allow cargo barge traffic between Aswan and the Mediterranean Sea. Recently, many locks have been refurbished and their operation conditions

\subsection{Cargo Transport Vessels}

Cargo vessels are mainly used in the transportation of goods, liquid bulk, finished products and raw materials along the River Nile and main irrigation canals. They are about 50 to 52 $\mathrm{m}$ length, $7.5 \mathrm{~m}$ width and about 1.5 to $2 \mathrm{~m}$ draft. According to Thabet et al (2006) [14], they are classified according to their way of operation and arrangements such as Nile sailing barges, self- improved. However, such improvement has not accomplished the hopeful economic growth. Only the tourism sector has flourished a little because of the increase in river cruising activities, especially between Aswan and Luxor cities. Here is a detailed description of the navigation vessel status along the River Nile.

propelled barges, pusher barge and pushed dumb barges and pusher barge and pushed dumb. On the other hand, operation of such vessels completely depends on the type of transported goods, trip distance and the possibility of passing through navigation locks.

According to statistics published by (RTA, 2006) [13], the annual cargo transported through the River Nile system during year 2006 is about 3.0 million metric tons which is equivalent to 
about $1 \%$ of the total transported goods in Egypt. About 1.5 million tons of which is transported between Cairo and Aswan, while the remaining amount (about 1.5 million tons) is transported between Cairo and Alexandria through El-Rayah El-Beheiry and El-Nubaria canal. Recently, the government has been interested in developing the inland transport from $1 \%$ till $8 \%$ of the total transport in Egypt. According to information declared by RTA chairperson in 2008, the number of some types of licensed registered ships with their total tonnage dead weight was given as follows:

- A fleet of 288 vessels (2 combined units) of total registered tonnage equal to 99000 metric tons;

- A fleet of 1643 vessels of self-propelled barges with total registered tonnage equal to 186000 metric tons; and

- A fleet of 473 tugs of total horse power 50922 $\mathrm{HP}$ with total registered tonnage equal to

\section{0 metric tons.}

\subsection{Tourist Transport Vessels}

River Nile Flotels are a particular type of passenger and tourist vessels that are mainly designed to transport tourists along the Nile and suit operation in shallow water depths according to a study report by (NRI, 2004) [15]. This ship type is self-propelled and has various design parameters such as a total length ranging between 27 and 109 $\mathrm{m}$ and width between 5.6 and $16.2 \mathrm{~m}$. This type of ship is portrayed by Thabet et al (2006) [14] and illustrated in Fig. 1. It is mainly operated through the River Nile main waterway, south of Egypt between Aswan and Luxor where most of which are five stars. Only a limited number of those units are modified for serving as floating restaurants as shown in Fig. 2. and local tours which are very popular in Egypt. They are mainly concentrated and operated within Cairo area.

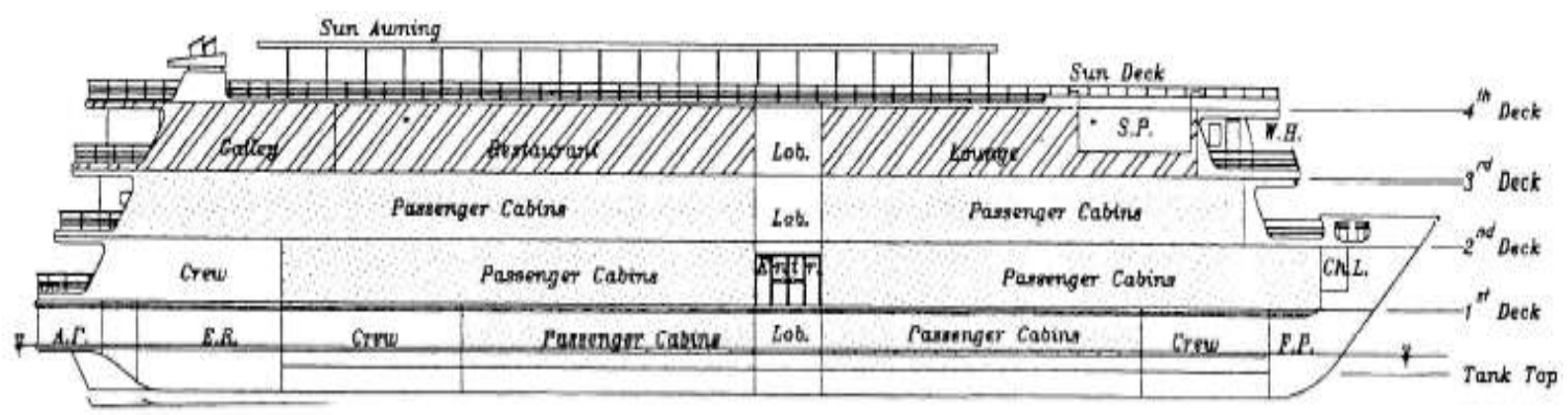

Fig. 1: An example of a four- deck floating hotel (Source: Thabet, 2006)

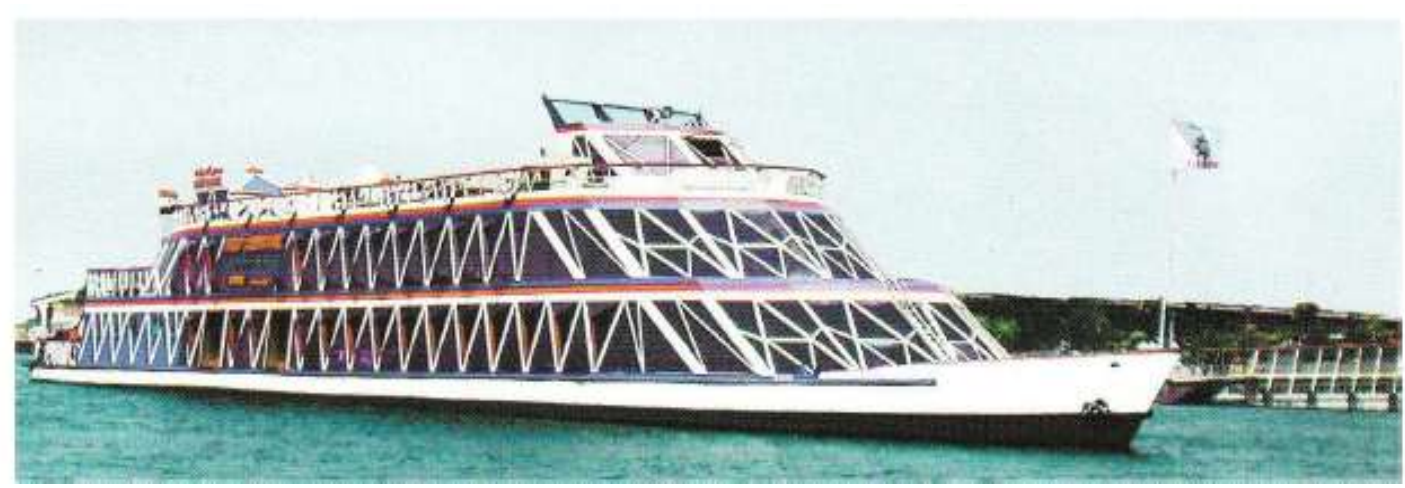

Fig. 2: An example of a floating restaurant (Source: Thabet, 2006)

\section{Study Objective}

The present study focuses on the potential docking problem facing the flotels along the River Nile in Egypt. The problem has been aggravating since 2006 because of the rapid increase in the number of flotels with no corresponding increase in the docking shore lengths. The paper intends to assess this problem at the existing docking sites along the river reach between Aswan and Luxor cities, south of Egypt and propose appropriate solutions.

\section{Materials and Methods}

\subsection{Study Area}

Aswan and Luxor are two cities located south of Egypt as shown in Fig. 3. They are about 221 
$\mathrm{km}$ apart. They are famous for ancient Egyptian tourist attractions. Tourists from almost every place of the world flock to Egypt every year, especially in winter where the weather is warm, to enjoy visiting such attractions. Accordingly, the River Nile reach within this region always abounds in tourist cruising. The number of cruises has been increasing over time to absorb all the tourists. This increase has made it necessary to provide enough berths for docking the flotels along this reach, especially at the locations of such attractions.

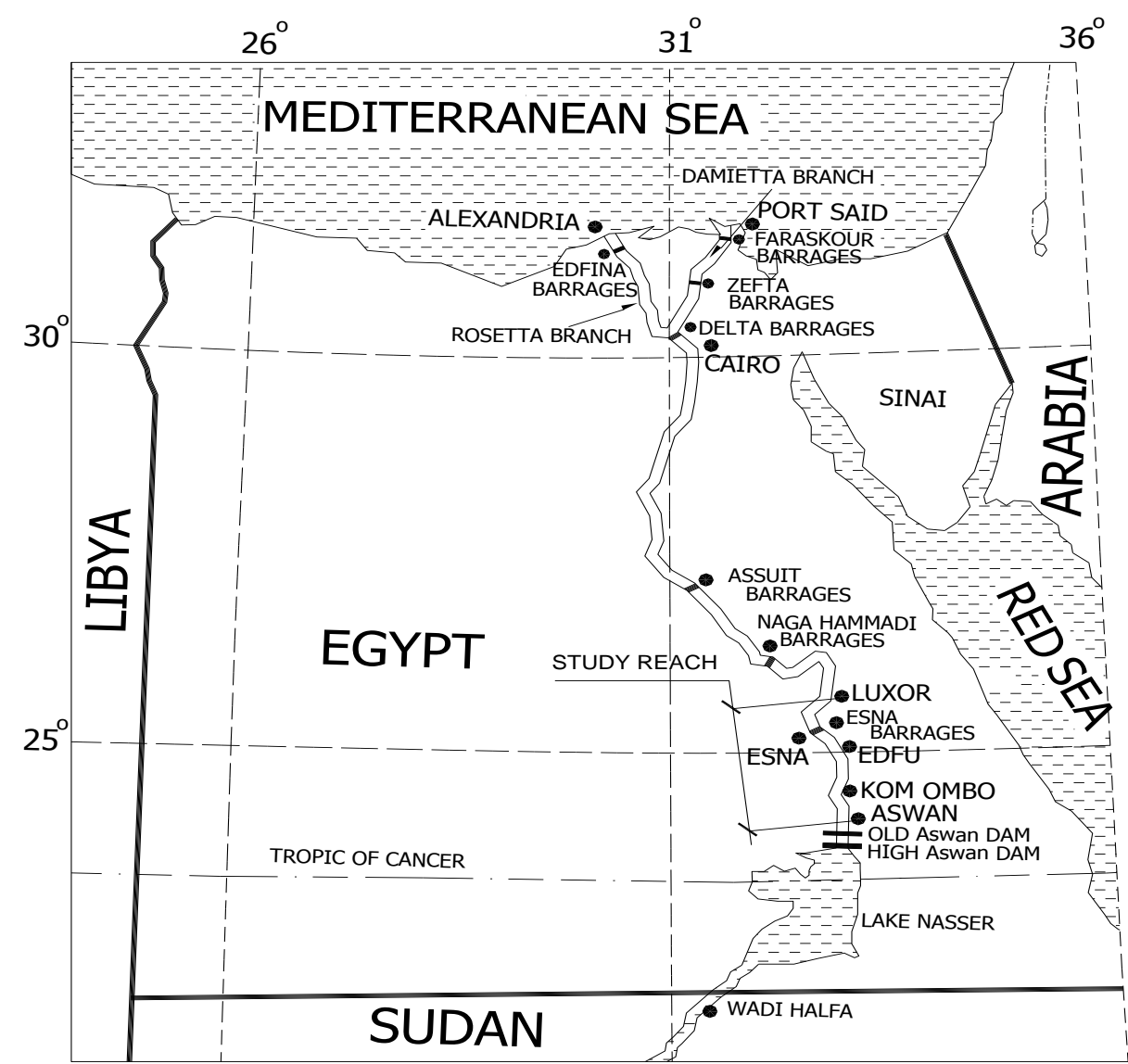

Fig. 3: Locations of Aswan, Kom Ombo, Edfu, Esna and Luxor throughout the Study Reach, South of Egypt (Source: NRI database, 2021 [16])

\subsection{Data Collection}

According to the Floating Hotel Association "FHA", (2006) [17] which is affiliated to the Ministry of Tourism and due to the regulating rules of cruising between Cairo and Luxor, a maximum number of 310 Flotels have been found to be concentrated in operation between Aswan and Luxor cities during year 2006. This number had been increasing since 1964 until 2006. Then, it started to decline to 280 in 2008 then to 268 in 2017 according to (Hader, 2017) [18] who attributed this to the state of instability that Egypt underwent during this period. This period witnessed a large decline in the tourist activities, especially starting from 2011 when the Egyptian Revolution broke out. Table 2 and Fig. 4 show the growing status of the Flotels between Aswan and Luxor.

Table 2: Growing Status of Floating Hotels between Aswan and Luxor cities (Source: FHA, 2007)

\begin{tabular}{cccccccc}
\hline No. & Year & New units & $\begin{array}{c}\text { Total } \\
\text { units }\end{array}$ & No. & Year & New units & $\begin{array}{c}\text { Total } \\
\text { units }\end{array}$ \\
\hline 1 & 1964 & 2 & 2 & 21 & 1993 & 23 & 194 \\
2 & 1966 & 1 & 3 & 22 & 1994 & 6 & 200 \\
3 & 1975 & 1 & 4 & 23 & 1995 & 3 & 203 \\
4 & 1976 & 1 & 5 & 24 & 1996 & 11 & 214 \\
5 & 1977 & 2 & 7 & 25 & 1997 & 8 & 22 \\
6 & 1978 & 4 & 11 & 26 & 1998 & 8 & 230 \\
7 & 1979 & 6 & 17 & 27 & 1999 & 13 & 243 \\
8 & 1980 & 8 & 25 & 28 & 2000 & 12 & 255 \\
\hline
\end{tabular}


Vol.42, No.1. January2023

\begin{tabular}{|c|c|c|c|c|c|c|c|}
\hline 9 & 1981 & 6 & 31 & 29 & 2001 & 13 & 268 \\
\hline 10 & 1982 & 11 & 42 & 30 & 2002 & 10 & 278 \\
\hline 11 & 1983 & 6 & 48 & 31 & 2003 & 4 & 282 \\
\hline 12 & 1984 & 5 & 53 & 32 & 2004 & 7 & 289 \\
\hline 13 & 1985 & 3 & 56 & 33 & 2005 & 9 & 298 \\
\hline 14 & 1986 & 5 & 61 & 34 & 2006 & 12 & 310 \\
\hline 15 & 1987 & 9 & 70 & 35 & 2008 & & 280 \\
\hline 16 & 1988 & 25 & 95 & 36 & 2010 & & 280 \\
\hline 17 & 1989 & 41 & 136 & 37 & 2012 & & 278 \\
\hline 18 & 1990 & 18 & 154 & 38 & 2015 & & 270 \\
\hline 19 & 1991 & 11 & 165 & 39 & 2016 & & 270 \\
\hline 20 & 1992 & 6 & 171 & 40 & 2017 & & 268 \\
\hline
\end{tabular}

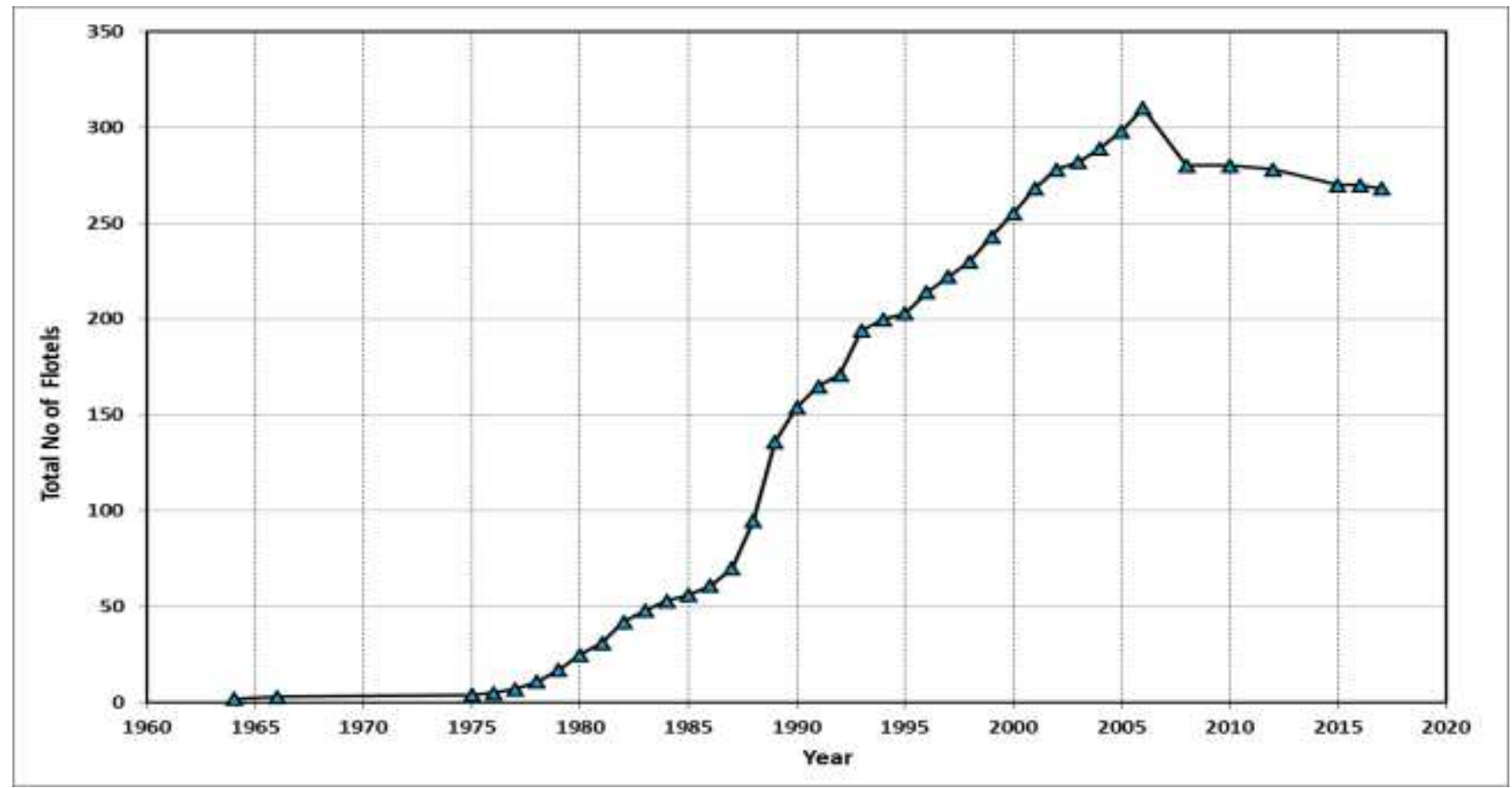

Fig. 4: Growing Status of Floating Hotels between 1964 and 2017

The maximum registered capacity (beds) of those flotels is 26700 passengers while the residency (occupancy) percentage during year 2006 was $70 \%$. Those flotels comprise various living standards. The most attractive ones are the five stars which amount to 189 vessels representing $61.2 \%$ of the total number as shown in Table 3 .

Table 3: Floating Hotels Standard Classification (Source: FHA, 2007)

\begin{tabular}{c|l|c|c}
\hline No. & Standard & Total Number & $\begin{array}{c}\text { Percentage } \\
(\%)\end{array}$ \\
\hline 1 & Two stars (**) & 5 & $1.5 \%$ \\
2 & Three stars (***) & 19 & $6.1 \%$ \\
3 & Four stars (***) & 53 & $17.2 \%$ \\
4 & Five stars (*****) & 189 & $61.2 \%$ \\
5 & Not in Operation & 44 & $14.0 \%$ \\
\hline \multicolumn{2}{l}{ Maximum total flotel Number } & 310 & $100 \%$ \\
\hline
\end{tabular}

\section{Methodology}

\subsection{Data Analysis}

Flotels mainly cruise along the river to let tourists enjoy the magnificent scenery of Upper Egypt and take them to the tourist sites (attractions) that are located on both sides of the
River Nile between Aswan and Luxor. As shown in Fig. 4 above, the number of flotels started to increase rapidly and almost linearly between years 1978 and 2006. This rapid increase made it necessary and even obligatory to increase the number of docking ports and berths, especially at the tourist attraction sites to cope with the increasing number of vessels. But due to 
exceptional circumstances which the country experienced such as a state of economic stagnation, a revolution in 2011 and Covid19 virus spread, the number of used flotels started to decrease a little between 2008 and the present time. However, it started to get better again and life is getting back to normal, especially after the discovery of a vaccine for Covid19. Therefore, the period of the emergency circumstances won't be considered in the analysis because it does not represent a data trend.

In order to meet the requirements of the docking process, the dimensions of the available flotels should be first investigated and analyzed to obtain the representative design vessel dimensions which are essential for designing the docking port. Accordingly, dimensions of the available vessels were examined for various inland navigation canals in general as listed in Table 4.

Table 4: Dimensions of Design Ship

\begin{tabular}{clccc}
\hline No. & \multirow{2}{*}{ Design Element } & \multicolumn{3}{c}{ Maximum dimensions } \\
\cline { 3 - 5 } & & $\begin{array}{c}\text { River Nile } \\
(\mathrm{m})\end{array}$ & $\begin{array}{c}\text { Main canals } \\
(\mathrm{m})\end{array}$ & $\begin{array}{c}\text { Damietta branch } \\
(\mathrm{m})\end{array}$ \\
\hline 1 & Vessel length (Ls) & 100.0 & 51.0 & 51.0 \\
2 & Vessel beam (Bs) & 15.0 & 7.5 & 7.5 \\
3 & Vessel draught (Ts) & 1.8 & 1.8 & 1.8 \\
4 & Flow water depth( $\mathrm{h})$ & 2.3 & 2.3 & 2.3 \\
\hline
\end{tabular}

Additionally, the available data of all the flotel lengths (NRI, 2004) [15] were analyzed and classified as listed in Table 5. This revealed that $61.29 \%$ of the lengths range between 70 and $80 \mathrm{~m}$. Similar analysis was carried out for the width and draft. Table 6 shows the final results which revealed that the representative flotel dimensions (length, width and draft) are $75 \mathrm{~m}, 15 \mathrm{~m}$ and $1.8 \mathrm{~m}$ respectively.

Table 5: Statistical analysis of vessel lengths

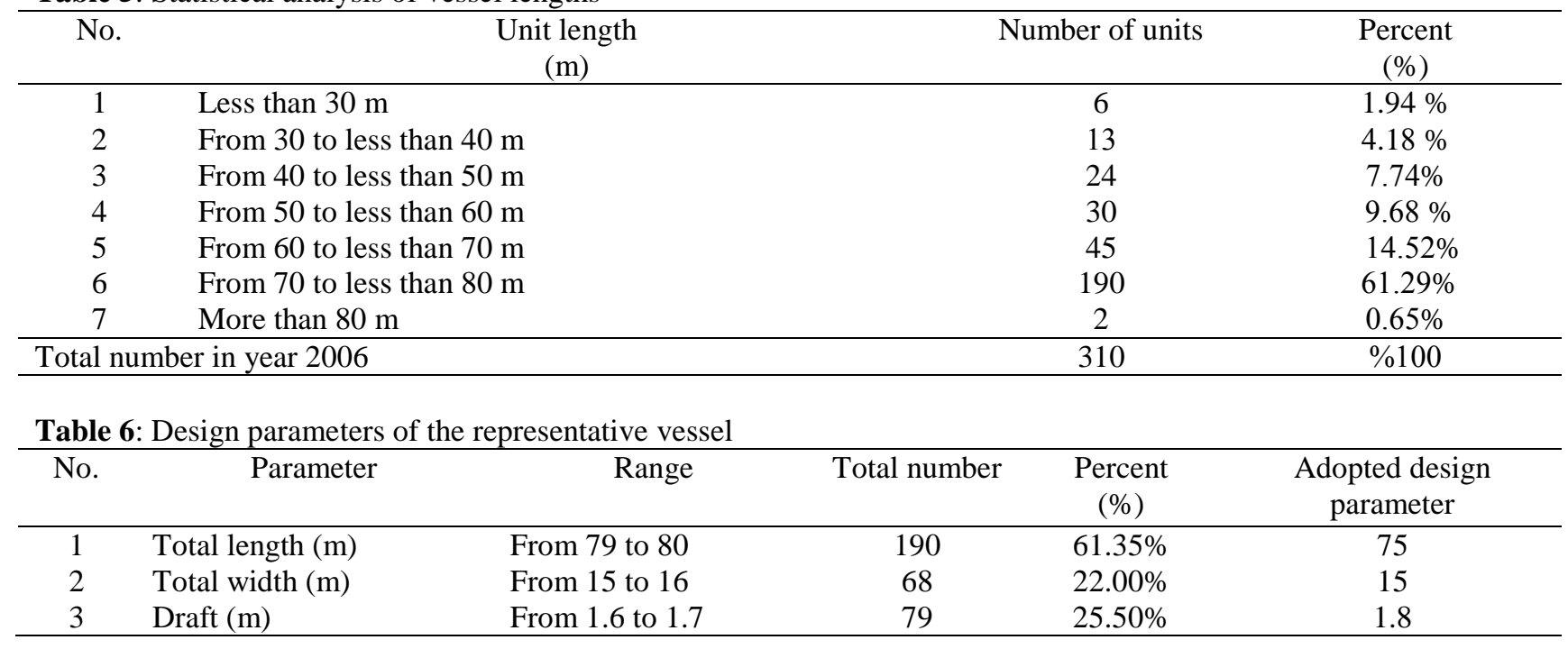

According to the above analysis, the required port docking length for a 75-m long flotel is taken as $90 \mathrm{~m}$ long considering a $15-\mathrm{m}$ space between every two consecutive flotels. Fig. 5 illustrates the inshore docking with which the flotels are docked at berths in single rows and sometimes forced in double and multiple rows due to berth length inadequacy. Also, Fig. 6 shows an example of the currently docking of flotels in multiple rows inshore at Luxor city. This queuing is due to inadequate available docking lengths. Such queuing causes disruption and losses to berth owners and tourist companies (Shahpanah et al, 2014) [19]. On the other hand, docking causes the flow velocity between the vessel hull bottom and the riverbed to increase (Tezdogan et al, 2015) [20]. When vessels are queued in multiple numbers, the flow velocity increases significantly, affecting the bed stability and causing morphological changes. 
Vol.42, No.1. January2023

Available docking length $(A L)$

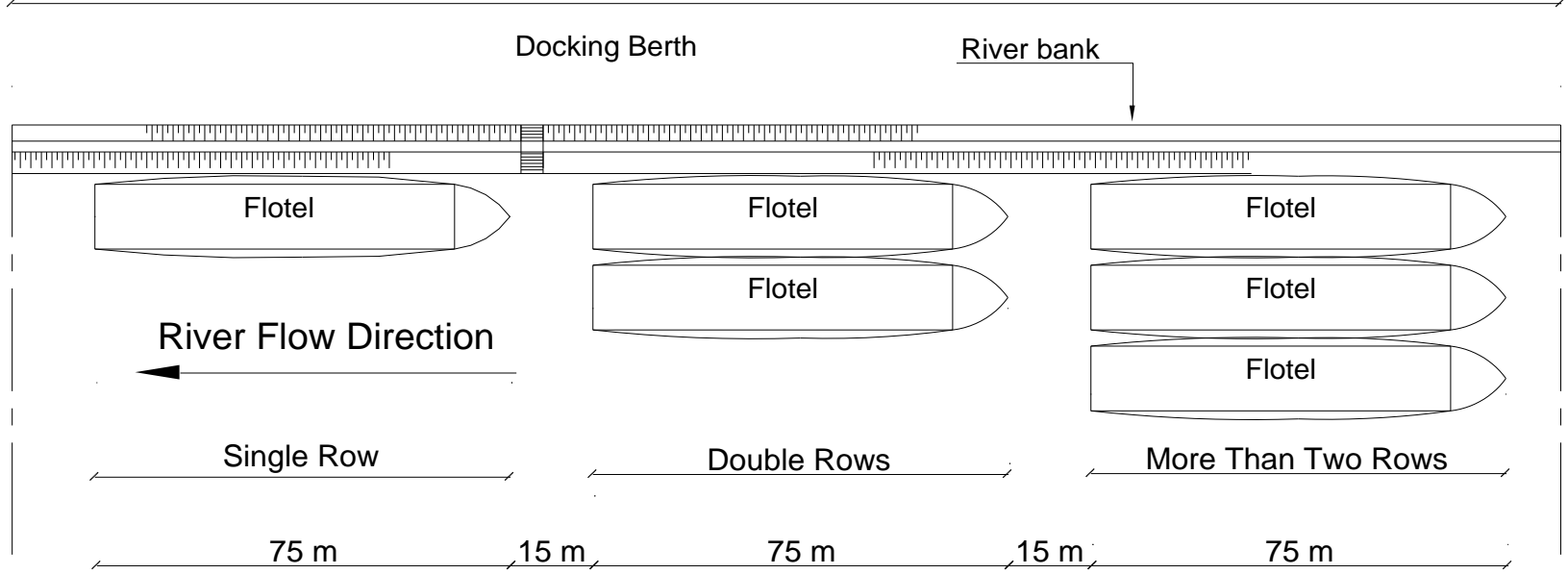

Fig. 5: Current docking in single, double and multiple rows

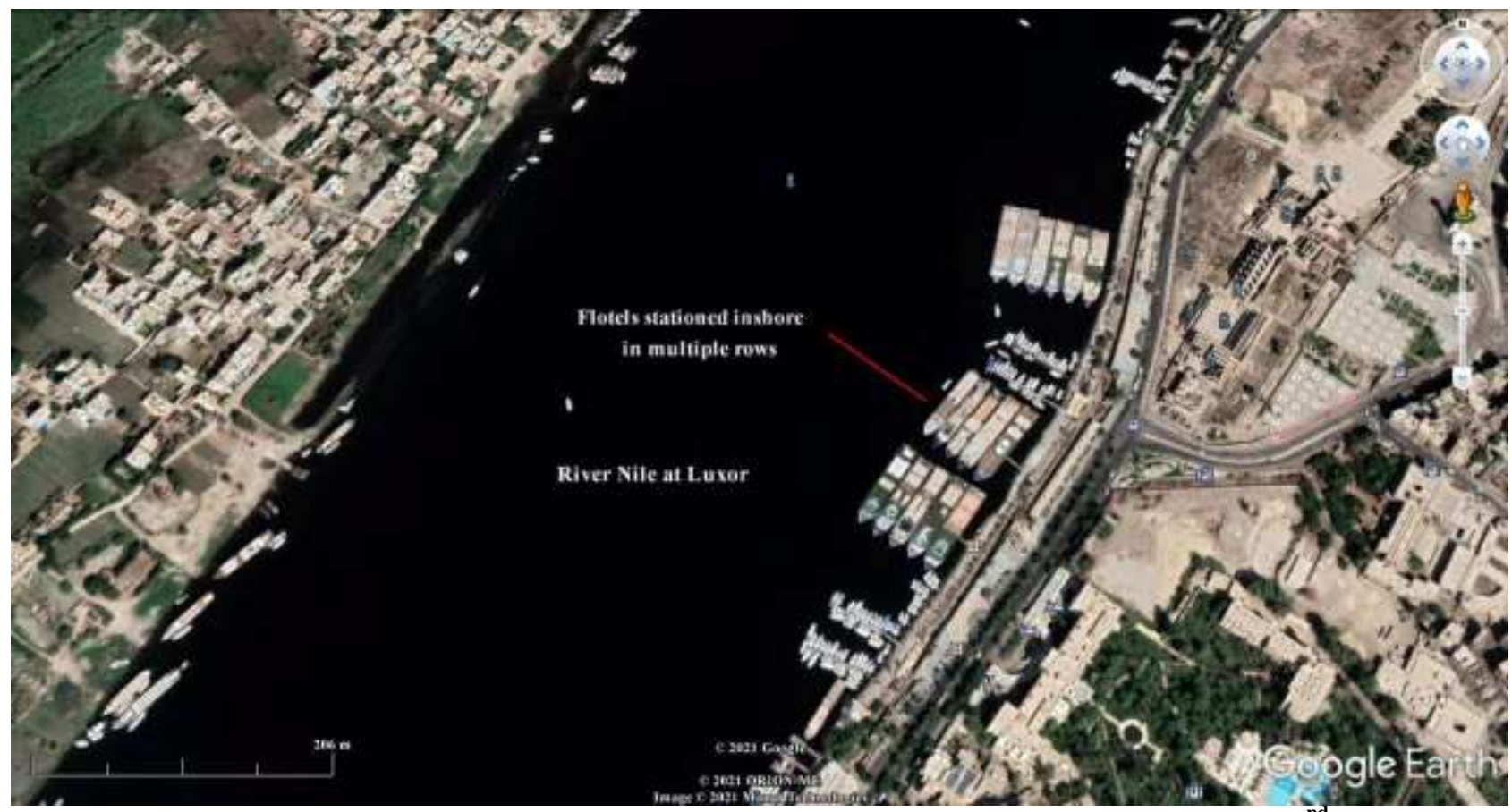

Fig. 6: Flotels stationed inshore in multiple rows at Luxor city (Source: Google earth, March $2^{\text {nd }}, \mathbf{2 0 2 1}$ )

The number of flotels expected between Aswan and Luxor at year 2035 was determined using linear extrapolation of historical data records neglecting the period of the above emergency circumstances between 2008 and the present time. Fig. 7 illustrates this number which will amount to 560 vessels. Correspondingly, the available and required docking lengths at every tourist site between Aswan and Luxor at years 2006 and 2035 were determined based also on the available historical data and future predictions. Several tourist companies, floating hotel owners, and some FHA members were consulted to achieve the needed technical parameters for the study as listed in Table 7. The feedback was as follows:
1. According to FHA, $10 \%$ of the registered flotels are under maintenance or repairing conditions at any time. The rest of the vessels would be either in cruising or docking conditions;

2. The average flotel sailing speed allowed is 13 $\mathrm{km} /$ hour according to RTA; and

3. Knowing the distance of the tour program $(221 \mathrm{~km})$, the total spent time for either cruising or docking can be determined for the operating vessels in years 2006 and 2035. Accordingly, the total numbers of both cruising and docking vessels for each tourist site could be determined as listed in Table $\mathbf{8}$. 
Vol.42, No.1. January2023

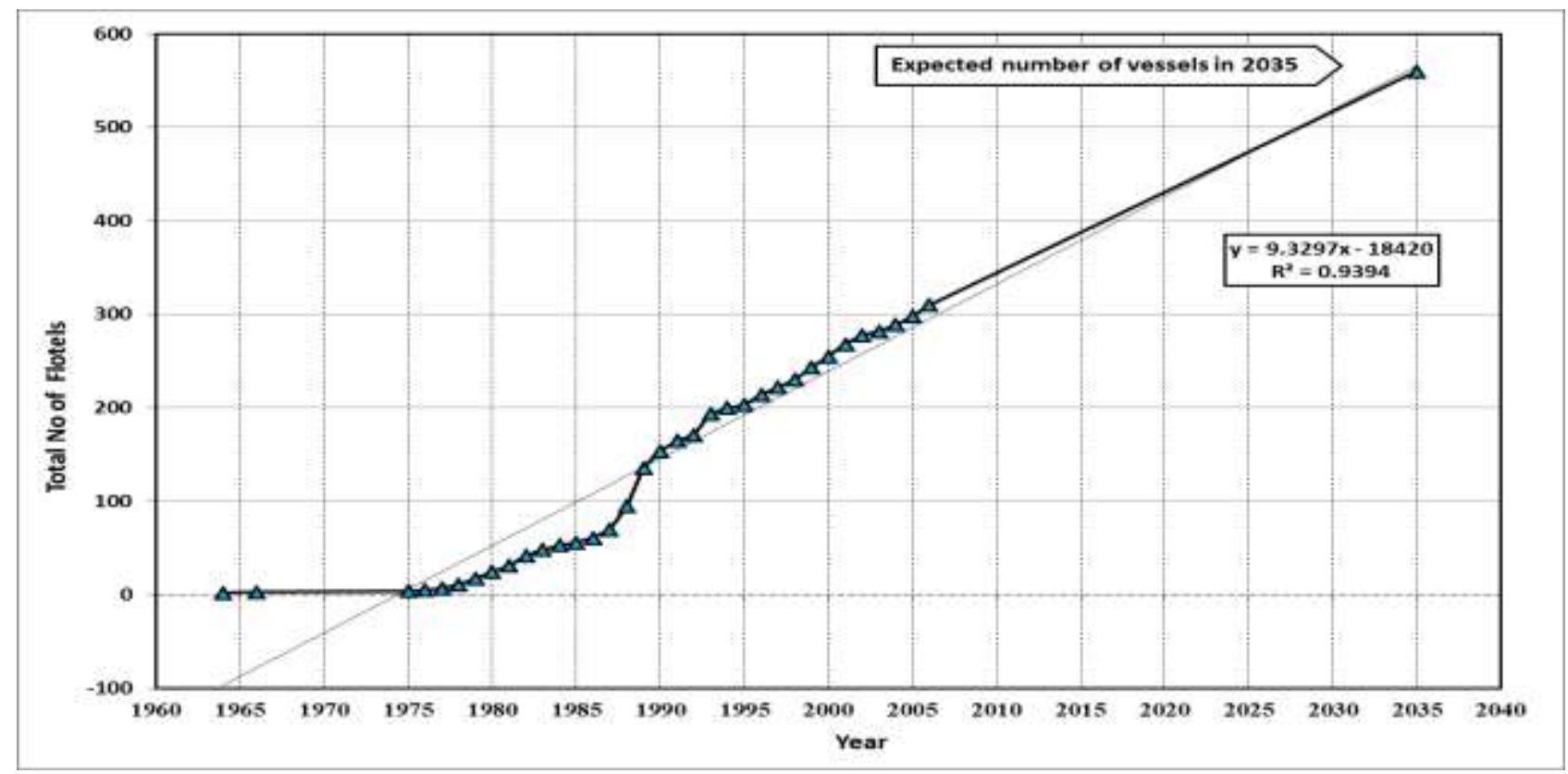

Fig. 7: Expected vessel numbers at year 2035

Table 7: Actual records for the docking sites at year 2006 (Source: FHA, 2006)

\begin{tabular}{clcccc}
\hline Site No & Tourist Site & $\begin{array}{c}\text { Location } \\
\text { D/S Old Aswan } \\
\text { Dam }(\mathrm{km})\end{array}$ & $\begin{array}{c}\text { Available port } \\
\text { lengths } \\
(\mathrm{m})\end{array}$ & $\begin{array}{c}\text { Docking time } \\
\text { (hours) }\end{array}$ & $\%$ docking time \\
\hline 1 & Aswan & 13.600 & 3650 & 36 & $26.7 \%$ \\
2 & Kom Ombo & 49.500 & 1097 & 7 & $5.2 \%$ \\
3 & Edfu & 114.000 & 1365 & 23 & $17.0 \%$ \\
4 & Esna & 166.000 & 984 & 48 & $15.6 \%$ \\
5 & Luxor & 224.000 & 7550 & 135 & $35.5 \%$ \\
\hline \multicolumn{2}{l}{ Total at year 2006} & & 14646 & $100 \%$ \\
\hline
\end{tabular}

It should be noted that the present available port

docking is supposed to occur only in a single row. lengths are computed on the basis that vessel

Table 8: Recorded data of docked and cruised vessels at year 2006 (Source: FHA, 2006) and predicted at 2035

\begin{tabular}{|c|c|c|c|c|c|c|}
\hline \multirow[t]{2}{*}{ No. } & \multirow[t]{2}{*}{ Term } & \multirow[t]{2}{*}{ Unit } & \multicolumn{2}{|c|}{ Year 2006} & \multicolumn{2}{|c|}{ Year 2035} \\
\hline & & & Data & Remarks & Data & Remarks \\
\hline 1 & Total number of recorded vessels & Unit & 310 & Recorded & 560 & Predicted \\
\hline 2 & Number of vessels out of operation & $\%$ & $10 \%$ & Expected & $10 \%$ & Expected \\
\hline 3 & $\begin{array}{l}\text { Expected number of vessels out of } \\
\text { operation }\end{array}$ & Unit & 31 & Computed & 56 & Computed \\
\hline 4 & $\begin{array}{l}\text { Operated vessels between Aswan } \\
\text { and Luxor }\end{array}$ & Unit & 279 & Computed & 504 & Computed \\
\hline 5 & $\begin{array}{l}\text { Trip distance between Aswan and } \\
\text { Luxor }\end{array}$ & $\mathrm{Km}$ & 221 & Actual & 221 & Actual \\
\hline 6 & Two-way trip distance & $\mathrm{Km}$ & 442 & Actual & 442 & Actual \\
\hline 7 & $\begin{array}{l}\text { Duration of a two-way trip for } 442 \\
\mathrm{~km}\end{array}$ & Day & 7 & Recorded & 7 & Recorded \\
\hline 8 & $\begin{array}{l}\text { Duration of a two-way trip for } 442 \\
\mathrm{~km}\end{array}$ & Hour & 168 & Computed & 168 & Computed \\
\hline 9 & $\begin{array}{l}\text { Average vessel speed between } \\
\text { tourist sites }\end{array}$ & $\mathrm{Km} /$ hour & 13 & Recorded & 13 & Recorded \\
\hline 10 & Cruising time for a single trip & Hour & 17 & Recorded & 17 & Recorded \\
\hline 11 & $\begin{array}{l}\text { Total cruising time during a two- } \\
\text { way trip }\end{array}$ & Hour & 34 & Recorded & 34 & Recorded \\
\hline
\end{tabular}


Vol.42, No.1. January 2023

\begin{tabular}{|c|c|c|c|c|c|c|}
\hline 12 & Percentage of cruised vessels & $\%$ & $20.2 \%$ & Recorded & $20.2 \%$ & Recorded \\
\hline 13 & $\begin{array}{l}\text { The instant number of cruised } \\
\text { vessels }\end{array}$ & Unit & $279 * 0.202=56$ & Computed & 102 & Computed \\
\hline 14 & $\begin{array}{l}\text { Total docking time during a two- } \\
\text { way trip }\end{array}$ & Hour & $168-34=134$ & Computed & 134 & Computed \\
\hline 15 & Percentage of docked vessels & $\%$ & $79.8 \%$ & Recorded & $79.8 \%$ & Recorded \\
\hline 16 & $\begin{array}{l}\text { The instant number of docked } \\
\text { vessels }\end{array}$ & unit & $279 * 0.798=223$ & Computed & $504 * 0.798=402$ & Computed \\
\hline
\end{tabular}

\subsection{Results}

In order to determine the number of docked vessels at each tourist site, the obtained data for the docking time and the corresponding percentages in Table 8 were used in calculations. Accordingly, the expected docked vessel number and the required docking length at each tourist site during years 2006 and 2035 were calculated as shown in Table 9. Also, the final required number of docking rows at each tourist attraction site in 2006 and 2035 were determined as shown in Table 10. They were calculated by dividing the required docking length (RL) by the available docking length (AL) and rounded up. Also, Fig. 8 illustrates the number of needed rows in the two comparison years. It is clear that the docking situation will be much more critical in the future, especially at Edfu and Esna cities.
According to this statistical data analysis, it has become clear now that the present and future docking situation at all tourist attraction sites along the study reach are critical and the current docking ports (berths) are not adequate. They have to be increased to absorb the expected increase in flotel numbers. The inshore docking arrangement system shown in Fig. 5 above will not help much in mitigating the problem even if the number of rows are increased because there will be long waits, delays in embarking and disembarking and other delays in maneuverability during docking and taking off. In short, the cruises are always delayed. Therefore, a new docking arrangement that can avoid the above shortcomings and cope with the present limited port lengths should be introduced to meet the required increasing port lengths successfully both at present and future.

Table 9: Number of docked flotels and required docking lengths at each tourist site

\begin{tabular}{|c|c|c|c|c|c|c|c|c|c|c|}
\hline \multirow[b]{2}{*}{$\begin{array}{l}\text { Tourist } \\
\text { Site }\end{array}$} & \multirow[b]{2}{*}{$\begin{array}{l}\text { Specified } \\
\text { length } \\
\text { for a } \\
\text { vessel } \\
\text { (m) }\end{array}$} & \multirow[b]{2}{*}{$\begin{array}{c}\% \\
\text { Docking } \\
\text { time }\end{array}$} & \multicolumn{4}{|c|}{ Docked vessels in 2006} & \multicolumn{4}{|c|}{ Docked vessels in 2035} \\
\hline & & & $\begin{array}{c}\text { Total } \\
\text { number } \\
\text { of } \\
\text { docked } \\
\text { vessels }\end{array}$ & $\begin{array}{c}\text { Number } \\
\text { of } \\
\text { docked } \\
\text { vessels }\end{array}$ & $\begin{array}{l}\text { Approx. } \\
\text { number } \\
\text { of } \\
\text { vessels }\end{array}$ & $\begin{array}{c}\text { Required } \\
\text { docking } \\
\text { length } \\
\text { for one } \\
\text { row }(\mathrm{m})\end{array}$ & $\begin{array}{c}\text { Total } \\
\text { number } \\
\text { of } \\
\text { docked } \\
\text { vessels }\end{array}$ & $\begin{array}{c}\text { Number } \\
\text { of } \\
\text { docked } \\
\text { vessels }\end{array}$ & $\begin{array}{c}\text { Approx. } \\
\text { number } \\
\text { of } \\
\text { vessels }\end{array}$ & $\begin{array}{l}\text { Required } \\
\text { docking } \\
\text { length for } \\
\text { one row } \\
\text { (m) }\end{array}$ \\
\hline Aswan & 90 & 0.267 & 223 & 59.541 & 59 & 5310 & 402 & 107.334 & 107 & 9630 \\
\hline $\begin{array}{l}\text { Kom- } \\
\text { Ombo }\end{array}$ & 90 & 0.052 & 223 & 11.596 & 12 & 1080 & 402 & 20.904 & 21 & 1890 \\
\hline Edfu & 90 & 0.170 & 223 & 37.91 & 38 & 3420 & 402 & 68.34 & 68 & 6120 \\
\hline Esna & 90 & 0.156 & 223 & 34.788 & 35 & 3150 & 402 & 62.712 & 63 & 5670 \\
\hline Luxor & 90 & 0.355 & 223 & 79.165 & 79 & 7110 & 402 & 142.71 & 143 & 12870 \\
\hline
\end{tabular}

Table 10: Final required number of docking rows at each tourist attraction site in 2006 and 2035

\begin{tabular}{|c|c|c|c|c|c|c|c|c|}
\hline \multirow[b]{2}{*}{ Tourist Site } & \multicolumn{4}{|c|}{ Situation in 2006} & \multicolumn{4}{|c|}{ Situation in 2035} \\
\hline & $\mathrm{AL}$ & $\begin{array}{c}\text { Row } \\
\text { Length (m) }\end{array}$ & RL & $\begin{array}{c}\text { Final } \\
\text { Req. Rows }\end{array}$ & $\mathrm{AL}$ & $\begin{array}{c}\text { Row } \\
\text { Length (m) }\end{array}$ & RL & $\begin{array}{c}\text { Final } \\
\text { Req. Rows }\end{array}$ \\
\hline Aswan & 3650 & 3650 & 5310 & 2 & 3650 & 3650 & 9630 & 3 \\
\hline $\begin{array}{l}\text { Kom } \\
\text { Ombo }\end{array}$ & 1097 & 1097 & 1080 & 1 & 1097 & 1097 & 1890 & 2 \\
\hline Edfu & 1365 & 1365 & 3420 & 3 & 1365 & 1365 & 6120 & 5 \\
\hline Esna & 984 & 984 & 3150 & 4 & 984 & 984 & 5670 & 6 \\
\hline Luxor & 7550 & 7550 & 7110 & 1 & 7550 & 7550 & 12870 & 2 \\
\hline
\end{tabular}

$\mathrm{AL}=$ Available docking length

$\mathrm{RL}=$ Required docking length 
Vol.42, No.1. January2023

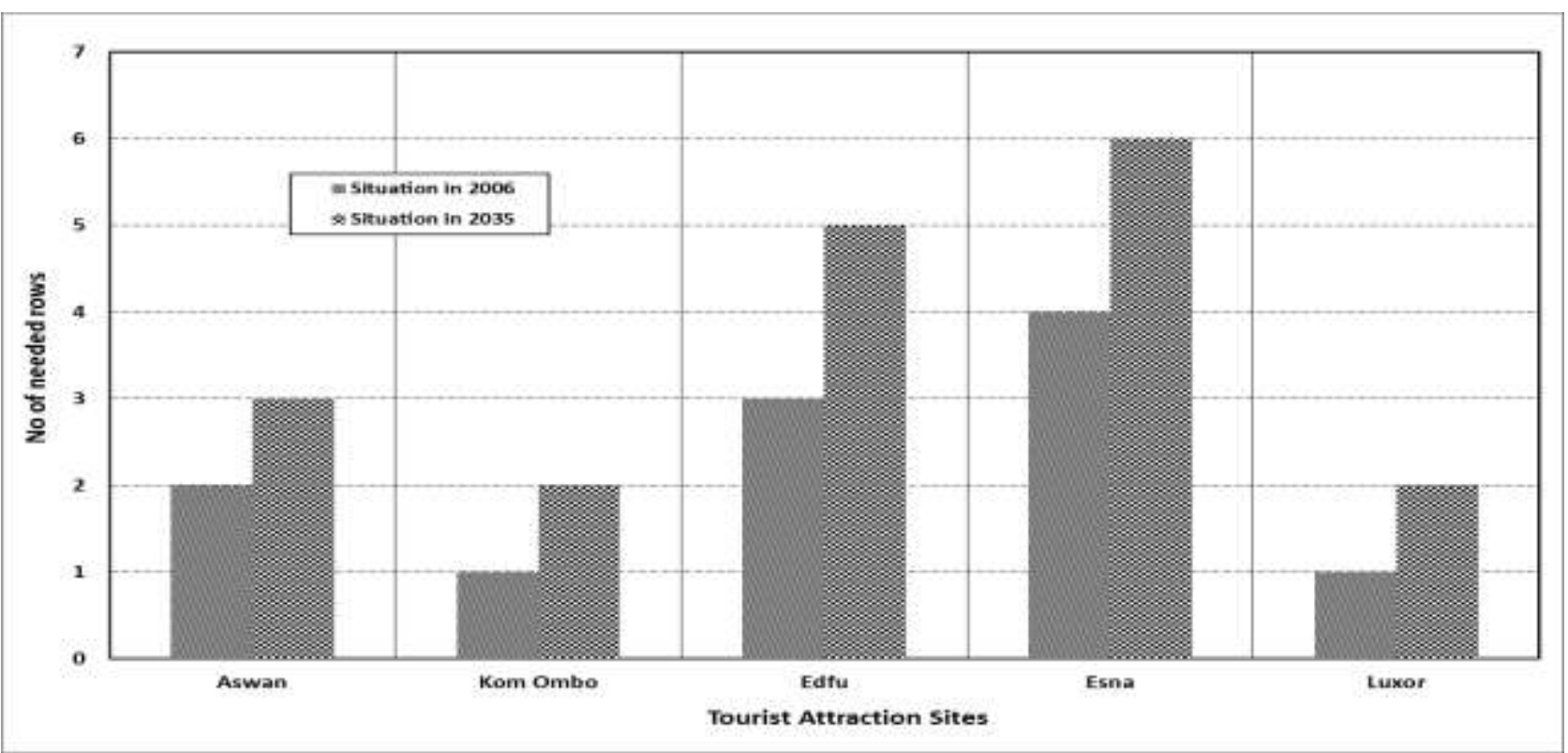

Fig. 8: Number of needed rows at the attraction tourist sites in 2006 and 2035

\section{Proposed Docking Arrangement}

In order to cope with the current and future critical docking capacities of the available berths at Aswan, Kom-ombo, Edfu, Esna and Luxor cities along the study reach, an arrangement of floating jetties is proposed to be used.

According to (Wikipedia, 2021) [21], a floating jetty is defined as a platform supported by several pontoons. It may be joined to the shore with a gangway. The pier is usually held in place by vertical poles referred to as pilings, which are embedded in the river floor or by anchored cables. Pontoons (also called floats) are airtight hollow structures designed to provide buoyancy in water. They are easy to assemble, disassemble and reassemble. The jetty can be stationed offshore so that vessels can dock at to load and unload cargo or passengers.

\subsection{Suitability and Validity}

To make sure that pontoons and thus the jetties are suitable for use in open channels, several studies have been conducted to investigate the hydraulic impacts of pontoons in rivers and harbors. A study made by (BWB, 2016) [22] on the Three Mills Wall River to investigate the potential hydraulic impacts of proposed floating pontoons attached to existing boat moorings near Strand East in Stratford, London on a weir nearby and on water levels elsewhere. Results revealed that the proposed pontoons had an insignificant impact on water levels and flow in their immediate vicinity, and the impact was negligible in the context of the wider river channel. Conversely, another study was conducted by (Straatsma,
2013) [23] to examine the hydraulic impacts of floating pontoons within a harbor with one inlet, especially flow velocities and siltation. Results demonstrated that the horizontal flow velocities inside the harbor with pontoons were more than twice as low compared to a harbor without pontoons. The pontoons form a barrier for the horizontal flow through a basin, which lower the velocities and change the flow patterns drastically.

From the above two studies, it could be concluded that pontoons have insignificant hydraulic impacts in open channels (rivers) while their impacts are considerable in closed water areas because of the siltation they produce. Therefore, the use of floating jetties as docking places in the River Nile will have no critical hydraulic impacts on bed morphology or river hydrodynamics. They cause neither sediment deposition nor major changes in flow velocities. Accordingly, they are encouraged and supported by this study.

\subsection{Considerations}

The jetty length can be tailored as required by joining or attaching a number of supporting pontoons together. This depends on the available pontoon dimensions and the required jetty arrangement length. Therefore, jetties can be used as terminal floating docks to accommodate flotel units providing that the following guidelines are followed:

- The position of the jetty should be far away from both the navigable channel and the maneuvering zone. It is also preferable to be parallel to the river flow direction in 
order not to impede the flow ;

- The proposed jetty arrangement should be offshore directly in front of the currently available docking berth. However, if the area specified for the arrangement is not adequate due to the closeness of the navigable channel or any other reason, the arrangement can be continued at the other side of the navigable channel or moved to another nearby area;

- The docking row length should be continuous as much as possible. Otherwise, it can be established discontinuous;

- The position of the jetty should provide safe docking with minimum flow depth of $2.3 \mathrm{~m}$ during minimum flow discharge release periods;

- In case the jetty is not joined to the shore by a gangway, shuttle small boats should be used to transport passengers, luggage and staff between the flotels and the river bank/shore; and

- The jetty should be held in place in such a way as to only allow for some vertical displacement to cope with the water surface fluctuation along the River Nile round the year.

\subsection{General Layout}

Fig. 9 illustrates a definition diagram for a proposed jetty arrangement for docking flotels at a tourist site. It is composed of a number of rows of 8-m wide jetties stationed offshore parallel to the riverbank within the limits of the available docking length "AL". These jetty rows are $60 \mathrm{~m}$ spaced to hold for two flotel rows and a maneuverability zone. If the area confined between the riverbank and the navigable channel is not sufficient to deploy the required number of rows, the redundant rows can be arranged at the other side of the navigable channel. It should be noted that jetties should be stationed parallel to the shore so that they don't occupy wide domain of water nor obstruct the river flow. Consequently, sediment deposition can be mitigated by being flushed downstream by flow currents.

\subsection{Application}

In order to check how this jetty arrangement can be applied on the tourist sites of this study, the available docking areas and the adjacent River Nile navigable channel were plotted on a map of each site as shown in Fig. 10. Then, the dimensions of the docking areas were determined to see if the required number of rows at each site fits within the area or not. This helps to identify the number of rows required beyond the navigable channel or elsewhere. Table $\mathbf{1 1}-\mathbf{a}, \mathbf{b}$ tabulates the results. 
Vol.42, No.1. January 2023

Available docking length (AL)

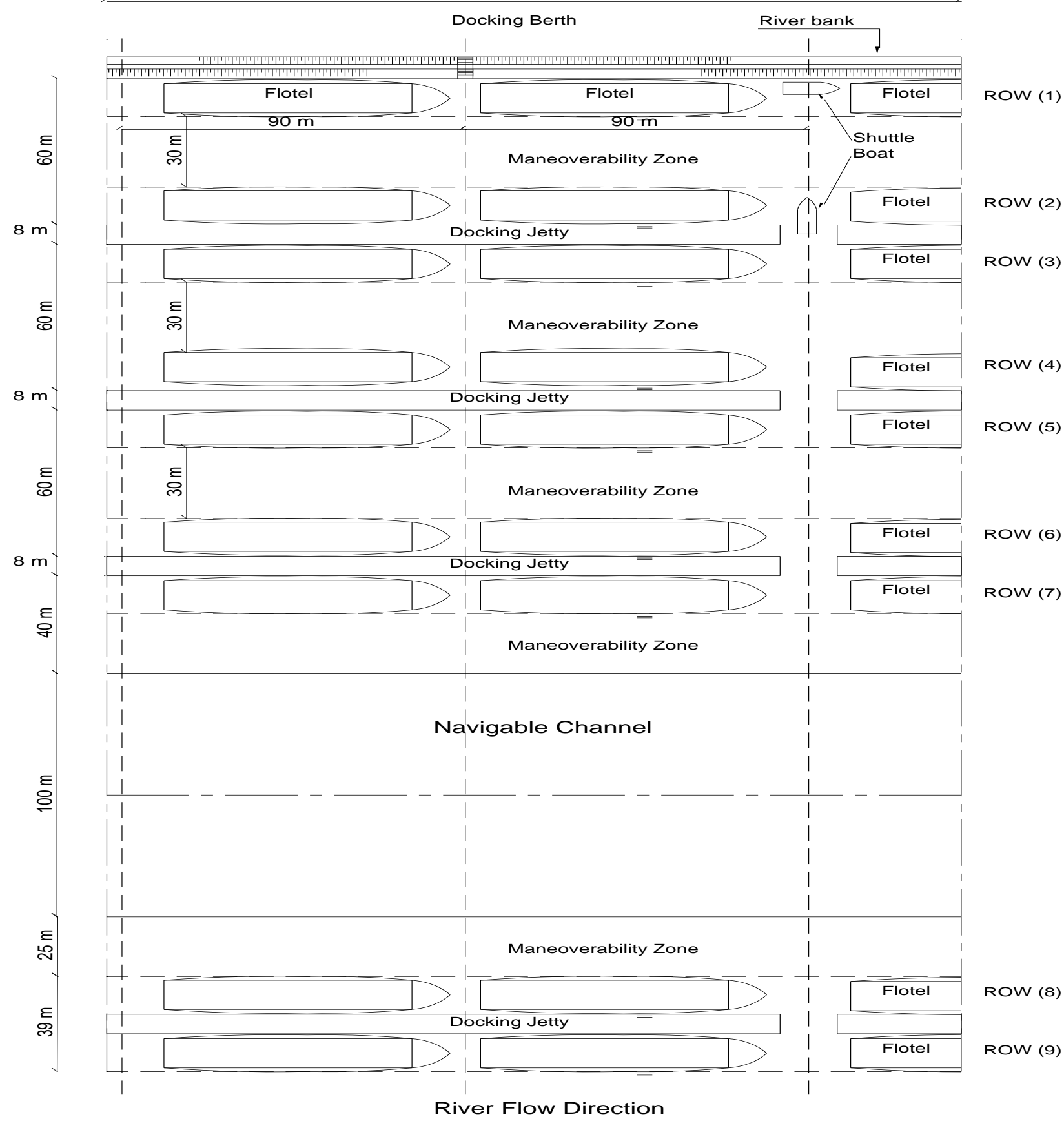

Fig. 9: A definition diagram of a proposed jetty arrangement for docking flotels at a tourist attraction site 
Vol.42, No.1. January2023

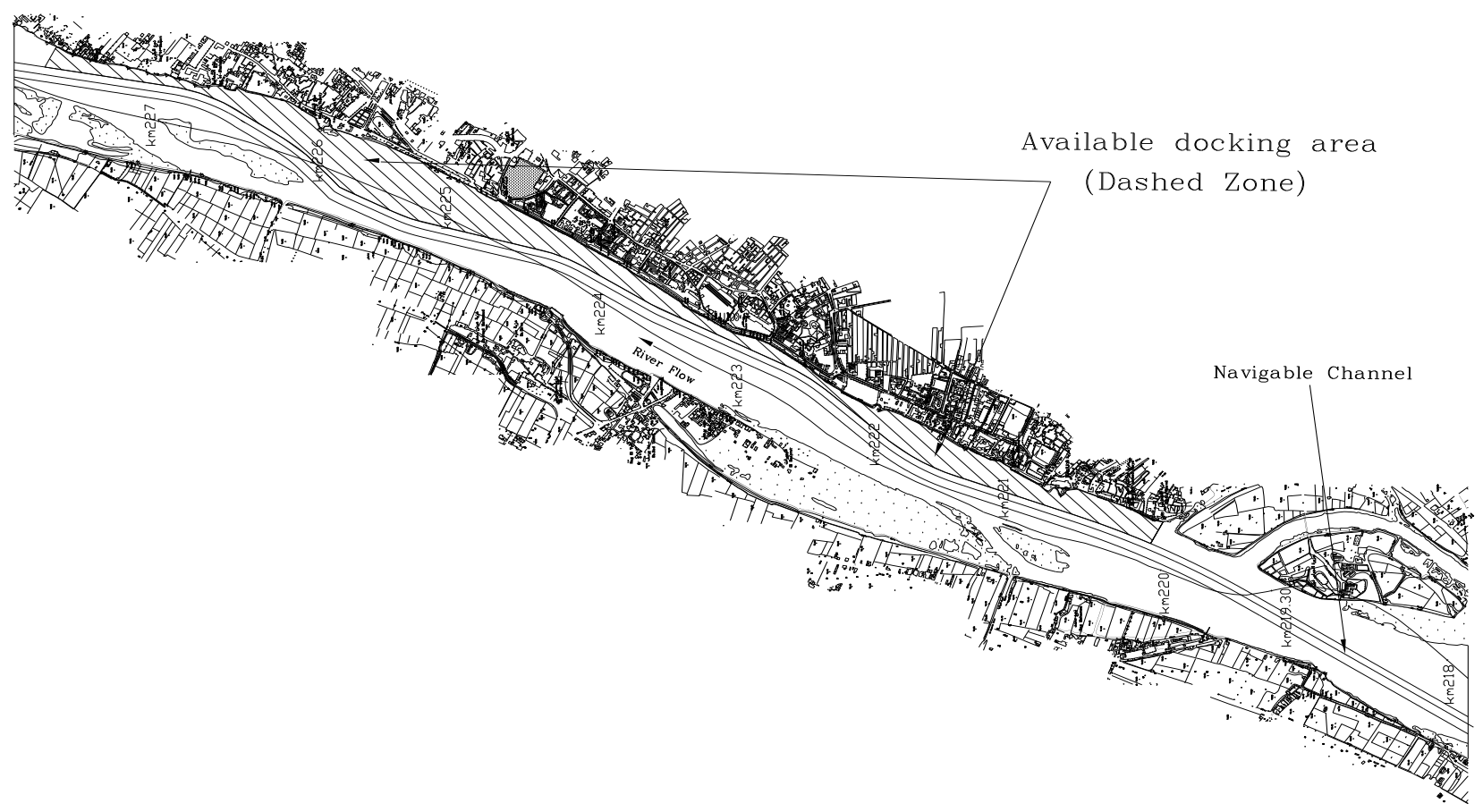

a- Luxor available docking Area

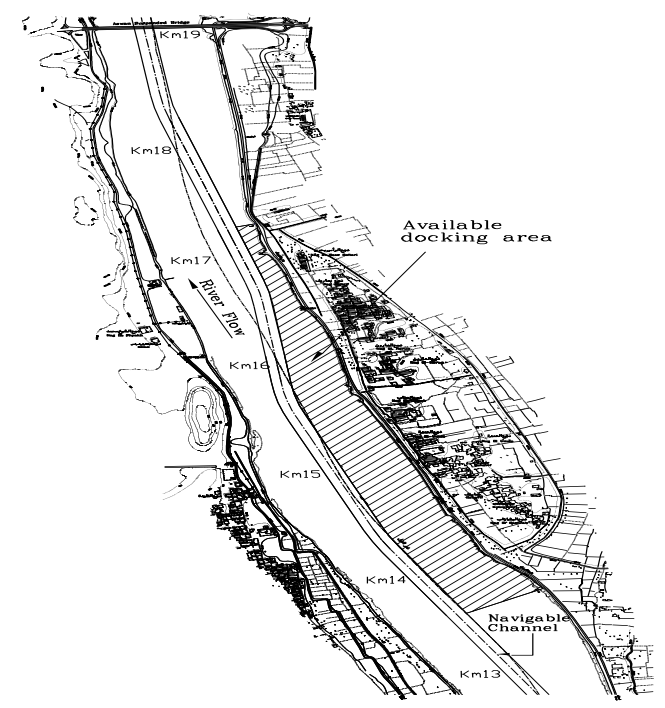

b- Aswan available docking area

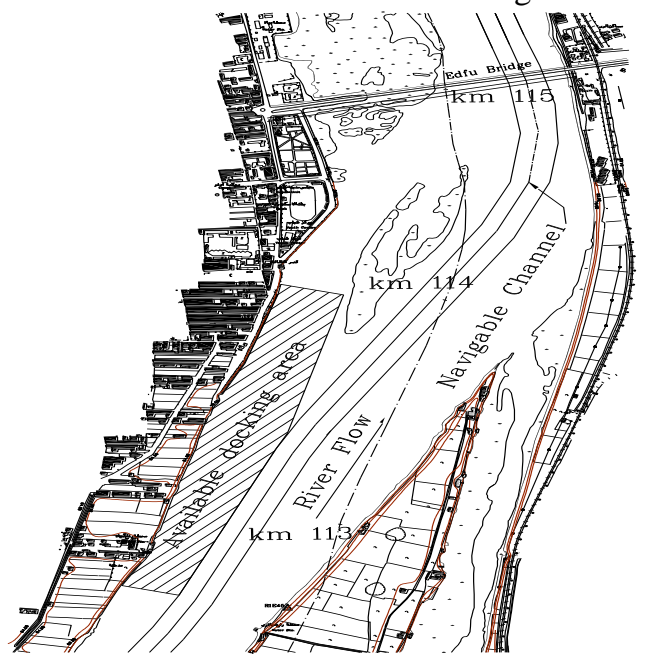

d- Edfu available docking area

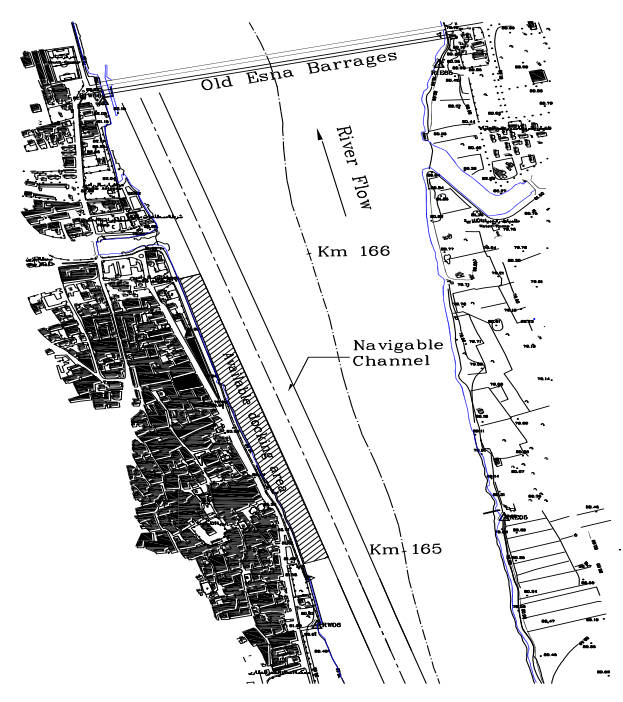

c- Esna available docking area

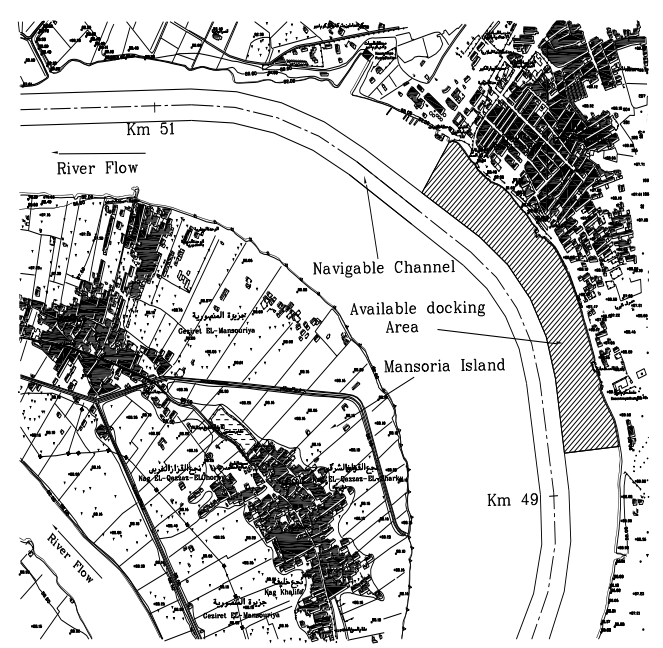

e- Kom-ombo available docking area 
Fig. 10: Available docking areas (hatched) and navigable channels at the current study tourist sites

It should be noted that the required docking width (RDW) is determined according to the proposed arrangement dimensions of Fig. 9 above. The space between the jetties is taken double the sum of two flotel beams (widths) according to (Boogaard, 1992) [24] to provide a maneuverability zone. It should also be noted that if the average width of the docking area shown in Table 11 is different from the actual width, the jetty arrangement should be implemented based on the actual width.

Table 11- a: Arrangement of rows within the available docking area with respect to the navigable channel (2006)

\begin{tabular}{|c|c|c|c|c|c|c|c|}
\hline $\begin{array}{l}\text { Tourist } \\
\text { Site }\end{array}$ & $\mathrm{AL}(\mathrm{m})$ & $\begin{array}{c}\text { Avg. } \\
\text { Width }(\mathrm{m})\end{array}$ & $\begin{array}{l}\text { ADA } \\
\left(\mathrm{m}^{2}\right)\end{array}$ & $\begin{array}{l}\text { Required } \\
\text { Rows }\end{array}$ & $\begin{array}{c}\text { RDW } \\
(\mathrm{m})\end{array}$ & $\begin{array}{l}\text { Row } \\
\text { Status }\end{array}$ & Remarks \\
\hline Aswan & 3650 & 282 & 1028657 & 2 & 68 & OK & Within the Navigable Channel \\
\hline $\begin{array}{l}\text { Kom- } \\
\text { ombo }\end{array}$ & 1097 & 172 & 189175 & 1 & 40 & $\mathrm{OK}$ & Within the Navigable Channel \\
\hline Edfu & 1365 & 188 & 256706 & 3 & 108 & $\mathrm{OK}$ & Within the Navigable Channel \\
\hline Esna & 984 & 63 & 61621 & 4 & 136 & Not OK & $\begin{array}{c}\text { Needs } 3 \text { rows beyond Nav. } \\
\text { Channel or elsewhere }\end{array}$ \\
\hline Luxor & 7550 & 167 & 1261733 & 1 & 40 & OK & Within the Navigable Channel \\
\hline
\end{tabular}

Table 11- b: Arrangement of rows within the available docking area with respect to the navigable channel (2035)

\begin{tabular}{|c|c|c|c|c|c|c|c|}
\hline $\begin{array}{l}\text { Tourist } \\
\text { Site }\end{array}$ & $\mathrm{AL}(\mathrm{m})$ & $\begin{array}{c}\text { Avg. } \\
\text { Width (m) }\end{array}$ & $\begin{array}{c}\text { ADA } \\
\left(\mathrm{m}^{2}\right) \\
\end{array}$ & $\begin{array}{c}\text { Required } \\
\text { Rows }\end{array}$ & $\begin{array}{c}\text { RDW } \\
(\mathrm{m})\end{array}$ & $\begin{array}{c}\text { Row } \\
\text { Status } \\
\end{array}$ & Remarks \\
\hline Aswan & 3650 & 282 & 1028657 & 3 & 108 & $\mathrm{OK}$ & Within the Navigable Channel \\
\hline $\begin{array}{l}\text { Kom- } \\
\text { ombo }\end{array}$ & 1097 & 172 & 189175 & 2 & 68 & $\mathrm{OK}$ & Within the Navigable Channel \\
\hline Edfu & 1365 & 188 & 256706 & 5 & 176 & $\mathrm{OK}$ & Within the Navigable Channel \\
\hline Esna & 984 & 63 & 61621 & 6 & 229 & Not OK & $\begin{array}{c}\text { Needs } 5 \text { rows beyond Nav. } \\
\text { Channel or elsewhere }\end{array}$ \\
\hline Luxor & 7550 & 167 & 1261733 & 2 & 68 & $\mathrm{OK}$ & Within the Navigable Channel \\
\hline
\end{tabular}

\section{Summary and Conclusion}

The present research study has aimed to investigate the docking situation of the flotels between Aswan and Luxor, south of Egypt. This is because this specific area abounds in ancient tourist attractions which attract tourists from all over the world. Flotel cruises along the River Nile reach within this area are organized to carry tourists to such attractions. In 2006, a docking problem was recorded because of the increase in the number of trips. Instead of docking in one row, flotels had to dock inshore and on each other in multiple rows. This caused long waits, delays in embarkation and disembarkation and other delays in maneuverability during flotel taking off. In addition, it caused losses to berth owners and tourist companies. As time went by, the problem aggravated. Accordingly, this study had to be conducted to assess the actual docking status at the past (2006) and the future (2035) and propose an appropriate solution. By analyzing the available historical data records, the study found that the number of used flotels had been increasing (ramping up) since 1964 almost linearly with no corresponding increase in the docking berth lengths. The number developed from one flotel in 1964 to 310 in 2006. Then, it reduced down to about 268 at the present time because of some exceptional circumstances that hit the country such as the 2011 revolution, world economic stagnation starting in 2008, and spread of pandemic Covid-19. However, life has recently started to be back to normal because of the re-stabilization of the country after the revolution and the development of new vaccines for controlling the pandemic. Accordingly, tourism is beginning to pick up again and the number of river cruises is expected to increase. Based on the historical data trends, the study expected the number of flotels would jump to 560 in 2035 . The study, also, revealed that the available docking shore lengths in 2006 at different tourist sites were too short to accommodate the cruising flotels. Further, it predicted that the situation in 2035 would be much worse. Accordingly, the number of the actual rows needed at each site was determined. In order to cope with such a critical and undesirable docking situation, a jetty arrangement for docking flotels was proposed to be applied at each tourist site. This system allows establishing more docking rows offshore at 
the site (within the docking area between the bank and the navigable channel) to compensate for the shortage of the available inshore docking lengths. In this way, the redundant number of flotels can be assimilated and the docking situation is mitigated. The proposed jetty arrangement was applied at each tourist site to see how the jetty rows would be stationed with respect to the navigable channel paths. A definition diagram for the arrangement was introduced with proposed dimensions. Also, maps for the different tourist sites were introduced to show the available docking areas that are confined between the current navigable channel paths and the river bank.

In conclusion, the study could investigate and analyze the flotel docking problem between Aswan and Luxor in detail. It clarified that the current docking inshore in multiple rows causes tourists to suffer greatly because of delays in flotel taking off and difficulties in embarkation, disembarkation, and maneuverability. Moreover, docking causes the flow velocity between the vessel hull bottom and the riverbed to increase. When vessels are queued in multiple numbers, the flow velocity increases significantly, affecting the bed stability and causing morphological changes. Also, it indicated with supportive evidence from the literature that docking in closed areas such as ports slows down current speeds significantly causing siltation and bed morphological changes that always require frequent dredging and maintenance works. Therefore, the study proposed a practical solution that can avoid the previous problems. It is an arrangement of spaced jetties that disallow the docked flotels to cause obstruction to water currents or produce any sediment accumulations. Thus, the proposed solution is believed to have insignificant impacts on river hydrodynamics and bed morphology, especially in open channels.

\section{Recommendations}

1.Riverbed morphological changes should be monitored round and downstream such docking places.

2.The environmental impacts that may result from the docking of flotels inside the river should be investigated thoroughly in other separate studies.

3. River pollution and water quality should also be monitored regularly at the proposed docking sites.

\section{Acknowledgements}

The authors would like to thank Prof. \Ahmed Fahmy, an Emeritus Professor at the Hydraulic Research Institute (HRI) for his valuable support and advice. Indeed, he has proved to be a good support. The authors also wish to thank NRI administration for providing all the data necessary to complete this work. The authors would like to appreciate the efforts of the Floating Hotel Association (FHA) of the Ministry of Tourism for providing the required information for conducting this present research. The authors also would like to thank the reviewers of this work for their strenuous efforts and constructive remarks and comments.

\section{Conflict of Interests}

The authors declare that there is no conflict of interests.

\section{Funding}

This research did not receive any specific grant from funding agencies in the public, commercial, or not-forprofit sectors.

\section{References}

[1] Wikipedia, 2020. https://en.wikipedia.org/wiki/Flotel. (Accessed Dec., 15th 2020).

[2] Admares, 2020. https://admares.com/marine/floating-realestate/floating-hotels. (Accessed Dec., 15th 2020).

[3] Lashine, A., 2015. Nile Inland Waterway Transport Development Strategy. Final Report by European Bank for Reconstruction and Development, Ministry of Transport and Ministry of Finance Public Private Partnership Central Unit, Oct., 2015.

[4] McAleer, J.B., Wicker, C.F., Johnsion, J.R., 1963. Design of Channels for Navigation. U.S. Army Engineers, 1963.

[5] Wicker, C.F., 1971. Economic Channels and Maneuvering Areas for Ships. Journal of Water Ways, Harbors and Coastal Engineering, Proc. ASCE, 97(WW3): pp. 443-454.

[6] Kray, C.J., 1973. Design of Ship Channels and Maneuvering Areas. Journal of Waterways, Harbors and Coastal Engineering Division, Vol. 99, No. WW1, pp. 89-110, ASCE, Feb. 1973.

[7] Herbich, J.B., 1986. Handbook of Coastal and Ocean Engineering. Volume 3, Harbors, Navigational Channels, 1986.

[8] Wallingford, H.R., (1996). Guidelines for the Hydraulic and Navigational Design of Approach Channels. Wallingford, Oxford shire OX10 8BA, Report No SR 475, July 1996.

[9] PIANC, 1997. Approach Channels: A Guide for Design. Final Report of the Joint PIANCIAPH Working Group II-30 in cooperation with IMPA and IALA, Supplement to 
